\title{
FAKTOR PENYEBAB KECELAKAAN LALU LINTAS PADA SISWA SEKOLAH MENENGAH ATAS DI KOTA SAMARINDA
}

\author{
FACTOR CAUSE OF ROAD ACCIDENTS AT SENIOR HIGH SCHOOL \\ STUDENTS IN SAMARINDA
}

\author{
Dina Lusiana Setyowati, Ade Rahmat Firdaus, Nur Rohmah \\ Fakultas Kesehatan Masyarakat, Universitas Mulawarman \\ E-mail: dina.setyowatik3@gmail.com
}

\begin{abstract}
Road accidents were the main causes of mortality at young ages, especially for gentlemen, it can also caused physical disabilities. Mortality rates which happened at young ages were caused by the low rates of their awareness perception due to the harm on traffic. This research was conducted to depict the causes of road accidents and safety riding while using vehicles of senior high school students in Samarinda. This research was conducted in nine senior high school which were chosen to represent each district. The total respondents were 315, which were taken using proportional random sampling, each district were represented by one school. The characteristic of respondents in this research was the students in 10th grade, who ride motorcycles to school. The data were collected using questionnaire, to avoid any bias, it was helped by enumerators. Each enumerator monitored 10 respondents. The data were analyzed using chi square with $\alpha 0.05 \%$. The results showed that the accidents rate was $30.8 \%$, the rates of using motorcycle due to has none to accompany were $39,4 \%$, due to the long distance were $11.7 \%$. There was relationship between accident rates and safety riding. The relationship between accident and rebelling yellow lamp was $p=0.015$, calling $p=0.041$, sending SMS $p=0.000$, smoking $p=0.01$ and riding with more than two $p=0.043$. Meanwhile riding with more than $60 \mathrm{~km} / \mathrm{h}$ speed, listening to the music, out of the street line, disobey the traffic signs have no relationship with road accidents. Factors that cause accidents are driving behavior called warning lights, using the phone, smoking and more than two people while driving.
\end{abstract}

Keywords: accident, high school, riding

\begin{abstract}
ABSTRAK
Kecelakaan di jalan raya merupakan faktor penyebab utama kematian pada usia muda, khususnya laki-laki dan menyebabkan kecacatan fisik. Tingginya angka kematian akibat kecelakaan lalu lintas pada usia muda karena rendahnya persepsi mereka terhadap risiko bahaya yang ada di jalan raya. Tujuan penelitian ini adalah untuk memberi gambaran tentang penyebab kecelakaan lalu lintas dan perilaku keselamatan berlalu lintas saat berkendara pada siswa SMA di Kota Samarinda. Penelitian dilakukan di 9 Sekolah Menengah di Kota Samarinda yang telah dipilih untuk mewakili setiap rayon. Jumlah responden sebanyak 315 orang diambil dengan menggunakan proportional Random sampling, masing-masing Kecamatan diwakili oleh satu sekolah. Kriteria responden dalam penelitian ini adalah siswa kelas $\mathrm{X}$ yang mengendarai motor menuju sekolah. Adapun pengumpulan data dengan menggunakan angket, untuk menghindari bias pengumpulan data dibantu dengan pendampingan enumerator. Setiap enumerator mendampingi 10 orang responden. Analisis data hasil penelitian dengan menggunakan chi square dengan $\alpha 0,05 \%$. Hasil penelitian menunjukkan angka kecelakaan sebesar 30,8\%, alasan penggunaan berkendara bermotor ke sekolah dikarenakan tidak ada yang mengantar sebesar 39,4\%, jarak sekolah yang jauh 11,7\%. Adapun hubungan antara kejadian kecelakaan dengan perilaku saat berkendara, menunjukkan adanya hubungan antara kejadian kecelakaan dengan perilaku melanggar lampu kuning $p=0,015$, menelepon $p=0,041$, mengirim SMS $p=0,000$, merokok $p=0,01$ dan berkendara lebih dari 2 orang $p=0,043$. Perilaku berkendaraan lainnya seperti memacu kendaraan lebih dari $60 \mathrm{KM} / \mathrm{jam}$, mendengarkan musik, melanggar marka jalan dan melanggar rambu-rambu Lalu Lintas tidak memiliki hubungan dengan kejadian kecelakaan. Faktor penyebab kecelakaan Lalu Lintas adalah perilaku saat berkendara yang melanggar peraturan yaitu melanggar lampu, menggunakan telepon, merokok dan berkendara lebih dari dua orang saat berkendara.
\end{abstract}

Kata kunci: bermotor, kecelakaan, SMA 


\section{PENDAHULUAN}

Kemacetan lalu lintas merupakan kejadian rutin di jalan-jalan di seluruh dunia. Ribuan orang kehilangan nyawa mereka di jalan setiap hari. Banyak jutaan lainnya mengalami kecacatan dalam kehidupannya. Anak-anak dan dewasa muda merupakan usia yang rentan dengan kejadian kecelakaan. Setiap jam setiap hari, empat puluh remaja meninggal akibat kecelakaan lalu lintas. Artinya setiap hari ada seribu lainnya keluarga harus mengalami kehilangan orang yang dicintai. Kecelakaan yang melibatkan sepeda motor dan kendaraan lainnya terjadi sekitar 50\% korban kecelakaan sepeda motor di Amerika Serikat (Administration, 2008). Mengingat tingkat kematian pengendara sepeda motor meningkat dari tahun 2007 sampai 2011 di Eropa (WHO, Global Status Report on Road Safety, 2013).

World Health Organization (WHO) menyatakan bahwa Sekitar 1.25 juta orang meninggal setiap tahun akibat kecelakaan Lalu Lintas jalan. Kecelakaan lalu lintas adalah penyebab utama kematian di kalangan anak muda, berusia 15-29 tahun. $90 \%$ dari kematian di dunia di jalan-jalan terjadi pada negara berpenghasilan rendah dan menengah, meskipun negara-negara ini memiliki sekitar setengah dari kendaraan di dunia. Separuhnya dari mereka yang meninggal di jalan di dunia adalah pengguna jalan yang berisiko seperti: pejalan kaki, pengendara sepeda dan pengendara sepeda motor. Jika tanpa tindakan, kecelakaan Lalu Lintas di jalan diperkirakan akan naik menjadi penyebab utama 7 kematian pada tahun 2030 (WHO, Road Traffic Injuries, 2015).

Angka kecelakaan di Provinsi Kalimantan Timur tahun 2011 mengalami penurunan. sebagaimana dilaporkan dalam data Kepolisian Republik Indonesia jumlah kecelakaan mencapai 1.347 kejadian dibandingkan tahun 2010 mencapai 1.767 kejadian. Jumlah korban kecelakaan sebanyak 2.115 orang. 463 orang diantaranya meninggal dunia. 517 orang mengalami luka berat. 1.135 orang mengalami luka ringan (Dishub, 2013). Sepanjang tahun 2013, tercatat 83 orang meninggal dunia dalam kecelakaan lalu lintas yang terjadi di Kota Samarinda, Kalimantan Timur. Meski peristiwa kecelakaan menurun dari tahun 2012, namun jumlah korban nyawa meningkat. Satuan lalu lintas Kepolisian Resor Kota Samarinda mencatat, pada tahun 2013 terdapat kecelakaan dengan 83 orang meninggal dunia. Sedangkan pada tahun 2012 kecelakaan mencapai angka 249 kejadian, namun yang meninggal 67 orang (Jalil, 2013).

Kecelakaan di jalan raya merupakan faktor penyebab utama kematian pada usia muda, khususnya laki-laki dan menyebabkan kecacatan fisik. Tingginya angka kematian akibat kecelakaan lalu lintas pada usia muda karena rendahnya persepsi mereka terhadap risiko bahaya yang ada di jalan raya. Pengendara berusia muda lebih sering menempatkan diri mereka pada situasi berbahaya misalnya dengan mengendarai motor dengan kecepatan tinggi, menerobos lampu merah, tidak menggunakan alat keselamatan berupa helm dan sarung tangan.

Hasil penelitian Rahmi didapatkan bahwa $84.5 \%$ siswa/i berkendaraan sepeda motor ke sekolah dan $56.8 \%$ responden memiliki kriteria tindakan kurang aman dalam berkendaraan roda dua dan $43.3 \%$ kriteria aman diantaranya berkendaraan sambil melakukan komunikasi dengan hand phone 51\% (Rahmi, 2009).

Penelitian lain yang dilakukan Rakhmani (2013) didapatkan bahwa remaja berpikir bahwa mereka cukup dewasa untuk mengendarai sepeda motor di jalan, tetapi dengan pengetahuan tentang mengemudi yang dangkal sering menyebabkan kecelakaan fatal. Pengetahuan mereka tentang kendaraan masih kurang karena masih merupakan hal baru bagi mereka. Kurang pengetahuan dan pengalaman tersebut membuat pengemudi remaja kurang tanggap terhadap situasi yang membahayakan sehingga berpotensi terjadinya kecelakaan di jalan raya (Rakhmani, 2013).

Berdasarkan latar belakang penelitian-penelitian yang sudah ada maka mengurangi jumlah kecelakaan di jalan raya yang dapat menyebabkan kecacatan atau kematian harus diprioritaskan oleh pihak pemerintah sebagai langkah-langkah pencegahan kecacatan dan kematian akibat kecelakaan lalu lintas. Pencegahan akibat kecelakaan lalu lintas juga dipengaruhi oleh persepsi mereka terhadap ancaman kecelakaan lalu lintas yang akan diterimanya. Untuk dapat mengurangi jumlah kecelakaan pada siswa SMA di masa yang akan datang maka perlu dilakukan identifikasi faktor-faktor perilaku keselamatan saat berkendara sehingga dapat dilakukan upaya promotif dan preventif berupa program pelatihan safety riding serta pemilihan duta safety riding bagi siswa SMA yang akan dilaksanakan pada tahun berikutnya. Tujuan penelitian ini adalah untuk mengetahui hubungan perilaku keselamatan berlalu lintas saat 
berkendara dengan kecelakaan lalu lintas pada siswa SMA di Kota Samarinda.

\section{METODE}

Penelitian ini adalah penelitian observasional dengan desain penelitian ini menggunakan analisis dengan pendekatan cross sectional study. Penelitian dilakukan di Sekolah Menengah Atas (SMA) di Kota Samarinda yang terdiri dari 10 Kecamatan dengan jumlah 36 sekolah. Jumlah responden sebanyak 315 orang diambil dari 9 SMA di Kota Samarinda. Teknik sampling yang digunakan adalah proportional Random sampling, masing-masing kecamatan diwakili oleh satu sekolah. Kriteria responden dalam penelitian ini adalah siswa kelas $\mathrm{X}$ yang mengendarai motor menuju sekolah.

Data primer didapatkan dengan memberikan angket yang telah dilakukan uji validitas dan reliabilitas pada 30 siswa SMA kelas X di Kota Samarinda yang tidak menjadi tempat penelitian. Pengumpulan data dibantu oleh enam orang enumerator yang telah diberikan pelatihan sebelumnya. Setiap enumerator mendampingi 10 orang responden.

Variabel dependen dalam penelitian ini adalah kecelakaan lalu lintas Sedangkan, variabel independen dalam penelitian ini adalah perilaku saat berkendara di jalan raya yang meliputi perilaku melanggar lampu kuning, menelepon, mengirim Short Message Service (SMS), merokok dan berkendara lebih dari 2 orang, memacu kendaraan lebih dari $60 \mathrm{KM} / \mathrm{jam}$, mendengarkan musik, melanggar marka jalan dan melanggar rambu-rambu Lalu Lintas.

Analisis data menggunakan perangkat komputer, untuk mengetahui hubungan antara variabel disajikan ke dalam bentuk tabel tabulasi silang. Analisis statistik menggunakan uji Chi-Square dengan $\alpha 0,05$.

\section{HASIL}

\section{Karakteristik Responden}

Karakteristik responden dalam penelitian ini terdiri dari pengalaman kecelakaan lalu lintas, alasan mengendarai sepeda motor, jenis kelamin, pekerjaan orang tua, dan kepemilikan Surat Ijin Mengemudi (SIM).

Tabel 1 menunjukkan distribusi responden bahwa $59,7 \%$ berjenis kelamin perempuan, sebanyak
Tabel 1. Karakteristik Responden Penelitian di Kota Samarinda Tahun 2018

\begin{tabular}{lll}
\hline Karakteristik & (n) & (\%) \\
\hline Pernah mengalami kecelakaan Lalu Lintas & \\
$\quad$ Ya & 97 & 30,8 \\
$\quad$ Tidak & 218 & 69,2 \\
Alasan mengendarai sepeda motor & & \\
$\quad$ Tidak Ada yang mengantar & 124 & 39,4 \\
$\quad$ Jarak rumah Jauh & 37 & 11,7 \\
$\quad$ Agar cepat sampai sekolah & 58 & 18,4 \\
$\quad$ Tidak ada angkutan umum dari & 31 & 9,8 \\
rumah ke sekolah & & \\
Lain-lain & 65 & 20,6 \\
Jenis Kelamin & & \\
$\quad$ Laki-laki & 127 & 40,3 \\
$\quad$ Perempuan & 188 & 59,7 \\
Pekerjaan Orang Tua & & \\
$\quad$ PNS & 56 & 17,8 \\
$\quad$ Swasta & 122 & 38,7 \\
Wiraswasta & 121 & 38,4 \\
Tidak Bekerja & 16 & 5,1 \\
Kepemilikan SIM C & & \\
Ya & 6 & 1,9 \\
Tidak & 309 & 98,1 \\
\hline Jumlah & 315 & 100 \\
\hline
\end{tabular}

$30,8 \%$ pernah mengalami kecelakaan lalu lintas, $39,4 \%$ menyatakan alasan mengendarai sepeda motor ke sekolah karena tidak ada yang mengantar, $38,7 \%$ orang tua bekerja swasta dan $1,9 \%$ responden menyatakan sudah memiliki surat ijin mengemudi (SIM).

\section{Perilaku Berkendara Siswa di Jalan Raya}

Safety riding atau keselamatan ber-kendara merupakan hal utama yang harus diperhatikan bagi pengendara baik sepeda motor maupun mobil. Hal utama ini seringkali diabaikan oleh para pengendara karena mungkin banyak dari elemen safety riding tersebut adalah hal-hal kecil dan merepotkan. Safety riding sangat penting diperhatikan dalam berkendara karena banyak kecelakaan lalu lintas di jalan yang disebabkan oleh pengendara, seperti data kecelakaan kendaraan bermotor yang terjadi di jalan raya dari kepolisian khususnya Kepolisian Daerah Metro Jaya menyatakan sekitar 80-85\% dari kecelakaan terjadi karena kelalaian dari para pengendara. 
Tabel 2. Perilaku Berkendara Siswa di Jalan Raya di Kota Samarinda Tahun 2018

\begin{tabular}{|c|c|c|}
\hline $\begin{array}{l}\text { Perilaku Saat } \\
\text { Berkendara }\end{array}$ & (n) & $(\%)$ \\
\hline \multicolumn{3}{|c|}{$\begin{array}{l}\text { Saat lampu lalu lintas berwarna kuning Saya } \\
\text { tetap memacu kendaraan }\end{array}$} \\
\hline Selalu & 75 & 23,8 \\
\hline Sering & 82 & 26,0 \\
\hline Kadang & 78 & 24,8 \\
\hline Tidak Pernah & 80 & 25,4 \\
\hline
\end{tabular}

Pernah menggunakan alat komunikasi atau HP untuk menelepon/menerima telepon sambil berkendara

$\begin{array}{lll}\text { Selalu } & 85 & 27,0 \\ \text { Sering } & 56 & 17,8 \\ \text { Kadang } & 67 & 21,3 \\ \text { Tidak Pernah } & 107 & 34,0\end{array}$

Pernah menggunakan alat komunikasi atau HP untuk menulis/membaca SMS sambil berkendara

$\begin{array}{lll}\text { Selalu } & 97 & 30,8 \\ \text { Sering } & 45 & 14,3 \\ \text { Kadang } & 63 & 20,0 \\ \text { Tidak Pernah } & 110 & 34,9\end{array}$

Pernah merokok sambil berkendara

$\begin{array}{lll}\text { Selalu } & 125 & 39,7 \\ \text { Sering } & 10 & 3,2 \\ \text { Kadang } & 7 & 2,2 \\ \text { Tidak Pernah } & 173 & 54,9\end{array}$

Pernah melanggar marka jalan

$\begin{array}{lll}\text { Selalu } & 80 & 25,4 \\ \text { Sering } & 58 & 18,4 \\ \text { Kadang } & 73 & 23,2 \\ \text { Tidak Pernah } & 104 & 33,0\end{array}$

Pernah melanggar rambu-rambu lalu lintas

$\begin{array}{lll}\text { Selalu } & 81 & 25,7 \\ \text { Sering } & 57 & 18,1 \\ \text { Kadang } & 70 & 22,2 \\ \text { Tidak Pernah } & 107 & 34,0\end{array}$

Pernah berkendara dengan kecepatan lebih dari $60 \mathrm{~km} / \mathrm{jam}$

\begin{tabular}{lll} 
Selalu & 51 & 16,2 \\
Sering & 100 & 31,7 \\
Kadang & 105 & 33,3 \\
Tidak Pernah & 59 & 18,7 \\
\hline
\end{tabular}

\begin{tabular}{|c|c|c|}
\hline $\begin{array}{l}\text { Perilaku Saat } \\
\text { Berkendara }\end{array}$ & (n) & $(\%)$ \\
\hline \multicolumn{3}{|c|}{$\begin{array}{l}\text { Pernah berboncengan sepeda motor lebih dari } \\
2 \text { orang }\end{array}$} \\
\hline Selalu & 84 & 26,7 \\
\hline Sering & 63 & 20,0 \\
\hline Kadang & 67 & 21,3 \\
\hline Tidak Pernah & 101 & 32,1 \\
\hline \multicolumn{3}{|c|}{$\begin{array}{l}\text { Pernah mendengarkan musik lewat HP/MP3 } \\
\text { player sambil berkendara }\end{array}$} \\
\hline Selalu & 69 & 21,9 \\
\hline Sering & 80 & 25,4 \\
\hline Kadang & 75 & 23,8 \\
\hline Tidak Pernah & 91 & 28,9 \\
\hline
\end{tabular}

Tabel 2 menunjukkan perilaku siswa saat berkendara di jalan raya, diketahui bahwa responden menyatakan selalu/sering sebanyak 49,8\% menyatakan bahwa saat lampu lalu lintas berwarna kuning tetap memacu kendaraan, 45,0\% menyatakan menggunakan alat komunikasi atau Hand Phone (HP) untuk menelepon/menerima telepon sambil berkendara, 46,0\% menggunakan alat komunikasi atau HP untuk menulis/membaca SMS sambil berkendara, 43,0\% merokok sambil berkendara, $44,0 \%$ melanggar marka jalan, 44,0\% melanggar rambu-rambu lalu lintas, $48,0 \%$ berkendara dengan kecepatan lebih dari $60 \mathrm{~km} / \mathrm{jam}, 47,0 \%$ selalu berboncengan sepeda motor lebih dari 2 orang, 48,0\% mendengarkan musik lewat HP/MP3 player sambil berkendara. Hasil penelitian ini menunjukkan bahwa perilaku siswa saat berkendara di jalan raya tidak aman atau berbahaya.

\section{Hubungan antara Variabel Dependen dan Variabel Independen}

Hasil analisis uji statistik menggunakan chi square $P$ value $<0,05$ didapatkan bahwa pada variabel tetap memacu kendaraan pada saat lampu Lalu Lintas berwarna kuning, pernah menggunakan alat komunikasi atau HP untuk menelepon/menerima telepon sambil berkendara, pernah menggunakan alat komunikasi atau HP untuk menulis/membaca SMS sambil berkendara, Merokok sambil berkendara, berboncengan sepeda motor lebih dari 2 orang memiliki hubungan yang signifikan dengan kecelakaan lalu lintas pada siswa SMA. Item melanggar marka jalan, melanggar rambu- 
Tabel 3. Hubungan antara Variabel Dependen dan Variabel Independen di Kota Samarinda Tahun 2018

\begin{tabular}{cccccc}
\hline Variabel & Selalu (\%) & Sering (\%) & Kadang (\%) & Tidak pernah (\%) & p \\
\hline \multicolumn{2}{l}{ Tetap memacu kendaraan pada saat lampu lalu lintas } & berwarna kuning & & \\
Mengalami & 19.6 & 17,5 & 34,0 & 28,9 &, $015^{* *}$ \\
Tidak mengalami & 25,7 & 29,8 & 20,6 & 23,9 &
\end{tabular}

Pernah menggunakan alat komunikasi atau HP untuk menelepon/menerima telepon sambil berkendara

$\begin{array}{lllll}\text { Mengalami } & 16,5 & 20,6 & 23,7 & 39,2 \\ \text { Tidak mengalami } & 31,7 & 16,5 & 20,2 & 31,7\end{array}$

Pernah menggunakan alat komunikasi atau HP untuk menulis/membaca sms sambil berkendara

\begin{tabular}{|c|c|c|c|c|}
\hline Mengalami & 14,4 & 21,6 & 25,8 & $38,1 \%$ \\
\hline Tidak mengalami & 38,1 & 11,0 & 17,4 & $33,5 \%$ \\
\hline
\end{tabular}

Merokok sambil berkendara

\begin{tabular}{|c|c|c|c|c|}
\hline Mengalami & 25,8 & 7,2 & 3,1 & $63,9 \%$ \\
\hline Tidak mengalami & 45,9 & 1,4 & 1,8 & $50,9 \%$ \\
\hline
\end{tabular}

Melanggar marka jalan

$\begin{array}{llllll}\text { Mengalami } & 20,6 & 15,5 & 24,7 & 39,2 \% & , 298 * \\ \text { Tidak mengalami } & 27,5 & 19,7 & 22,5 & 30,3 \% & \end{array}$

Melanggar rambu-rambu lalu lintas

\begin{tabular}{|c|c|c|c|c|}
\hline Mengalami & 18,6 & 15,5 & 24,7 & $41,2 \%$ \\
\hline Tidak mengalami & 28,9 & 19,3 & 21,1 & $30,7 \%$ \\
\hline
\end{tabular}

Berkendara dengan kecepatan lebih dari $60 \mathrm{~km} / \mathrm{jam}$

\begin{tabular}{|c|c|c|c|c|}
\hline Mengalami & 17,5 & 32,0 & 35,1 & $15,5 \%$ \\
\hline Tidak mengalami & 15,6 & 31,7 & 32,6 & $20,2 \%$ \\
\hline
\end{tabular}

Berboncengan sepeda motor lebih dari 2 orang

$\begin{array}{llllll}\text { Mengalami } & 22,7 & 13,4 & 28,9 & 35,1 \% & , 044 * * \\ \text { Tidak mengalami } & 28,4 & 22,9 & 17,9 & 30,7 \% & \end{array}$

Mendengarkan musik lewat HP/MP3 player sambil berkendara

\begin{tabular}{lllll} 
Mengalami & 16,5 & 26,8 & 25,8 & $30,9 \%$ \\
Tidak mengalami & 24,3 & 24,8 & 22,9 & $28,0 \%$ \\
\hline
\end{tabular}

rambu lalu lintas, berkendara dengan kecepatan lebih dari $60 \mathrm{~km} / \mathrm{jam}$, mendengarkan musik lewat HP/ MPEG-1 Audio Layer 3 (MP3) player sambil berkendara tidak memiliki hubungan signifikan dengan kecelakaan Lalu Lintas pada siswa SMA. Hasil analisis hubungan antara variabel dependen dengan variabel independen pada Tabel 3.

\section{PEMBAHASAN}

\section{Kecelakaan Lalu Lintas}

Kecelakaan lalu lintas adalah suatu peristiwa di jalan yang tidak disangka-sangka dan tidak disengaja, melibatkan kendaraan dengan atau tanpa pemakai jalan lainnya, mengakibatkan korban manusia atau kerugian harta benda (Peraturan Pemerintah No 43 Tahun 1993 Pasal 93). Kecelakaan lalu lintas pada umumnya terjadi karena berbagai faktor penyebab secara bersama-sama seperti pelanggaran atau tindakan kurang hati-hati para pengguna jalan (pengemudi dan pejalan kaki), kondisi jalan, kondisi kendaraan, cuaca atau pandangan terhalang. Secara umum bahwa penyebab terjadinya kecelakaan lalu lintas adalah faktor manusia itu sendiri (human error). Hasil penelitian ini menunjukkan bahwa perilaku berkendara pada siswa SMA di Kota Samarinda tidak aman atau berbahaya. 
Beberapa negara mengidentifikasi ada tiga penyebab utama kecelakaan lalu lintas yaitu faktor manusia, faktor kendaraan dan faktor jalan atau lingkungan. Ketiga faktor tersebut ada di Indonesia (Soehodho, 2009).

Faktor utama penyebab kecelakaan lalu lintas adalah faktor manusia. Manusia banyak melakukan pelanggaran terhadap aturan lalu lintas. Pelanggaran rambu lalu lintas merupakan salah satu penyebab terjadinya kecelakaan lalu lintas. Pelanggaran tersebut diakibatkan karena kesengajaan maupun kurangnya kontrol diri pada pengemudi terhadap peraturan yang berlaku. Pengendara sepeda motor yang melakukan pelanggaran terjadi karena rendahnya kontrol diri dari pengemudi. Sama halnya pada faktor kepribadian juga dapat memengaruhi pelanggaran sehingga dapat menyebabkan kecelakaan lalu lintas (Kusumadewi, 2012).

Tipe kepribadian terbagi menjadi dua bagian, yaitu kepribadian introvert dan kepribadian extrovert. Tipe kepribadian introvert cenderung menutup diri dari lingkungan sekitarnya, serta keputusan yang diambil hanya didasarkan oleh perasaan, pemikiran, dan pengalaman dari individu. Tipe kepribadian ini akan menimbulkan sifat ego sentries yaitu sifat yang lebih mementingkan diri sendiri dan kurang memperhatikan dan atau kurang menghargai orang lain, sehingga dalam berlalu lintas mudah menimbulkan kecelakaan, karena semua yang ada di sekitarnya dianggap hanya untuk kebutuhan dan kepentingannya sendiri. Misalnya helm yang tidak ditalikan sehingga saat kendaraan dilarikan dalam kecepatan tinggi, helm tersebut dapat terbang tertiup angin, hal ini sangat membahayakan pengendara yang ada di belakangnya; Sementara untuk kepribadian extrovert, seorang anak cenderung lebih aggressive, sehingga keputusan yang diambil berdasar dari pengalaman teman sekitarnya (Notoatmojo, 2010). Sifat agresif ini mempunyai ciri-cirinya kurang sabar, penuh rasa persaingan, mudah menyerang dan menyalahkan orang lain, sehingga kendaraan yang dikendarai dapat digunakan sebagai alat untuk melampiaskan nafsu agresifnya untuk menyerang orang lain, sehingga mudah terjadi kecelakaan.

Kazantzis, et al. menyebutkan bahwa insiden kecelakaan lalu lintas pengendara sepeda motor pada remaja yaitu $11 \%$, dan lebih dari $50 \%$ korban kecelakaan lalu lintas mengalami hyperarousal, gangguan ingatan, lebih emosional dan adanya gangguan kognitif dan social (Kazantzis, 2012).
Laki-laki dari usia muda, lebih cenderung mengalami kecelakaan lalu lintas di jalan daripada perempuan. Karena Laki-laki lebih cenderung tidak menaati peraturan yang ada, sedangkan perempuan lebih mementingkan peraturan yang ada. Menurut data kepolisian faktor pelanggaran yang dilakukan pengemudi yang kurang tertib berlalu lintas ini mencapai lebih dari $80 \%$ dari penyebab kecelakaan lalu lintas (Adinugroho, 2012).

Penelitian ini menunjukkan berbagai alasan mengapa pelajar mengendarai sepeda motor diantaranya tidak ada yang mengantar $(39,4 \%)$ serta sekolah yang jauh dari rumah $(11,7 \%)$. Hal ini menggambarkan bahwa saat ini sepeda motor menjadi pilihan praktis dan menjadi kebutuhan penggunaan sepeda motor di usia remaja menjadi hal penting, karena motor adalah kendaraan yang mampu mencapai tujuan dengan cepat dan merupakan bagian dari aktivitas kehidupan ke sekolah untuk para siswa. Pengemudi pemula memiliki peluang tiga kali lebih besar terlibat dalam kecelakaan dari pada pengemudi yang telah mahir. Lebih dari 27,4\% kecelakaan pada tahun 2004 melibatkan anak muda dan pengemudi pemula berusia $16-25$ tahun (Marsaid, 2013). Pengemudi pemula tidak di bekali dengan persiapan yang cukup mengenai keselamatan berlalu lintas seperti pengetahuan tentang safety riding, perilaku berkendara yang aman, dan kemampuan/skill berkendara ditunjukkan dengan kepemilikan SIM.

Surat Izin Mengemudi (SIM) adalah bukti registrasi dan identifikasi yang diberikan oleh Polri kepada seseorang yang telah memenuhi persyaratan administrasi, sehat jasmani dan rohani, memahami peraturan lalu lintas dan terampil mengemudikan kendaraan bermotor (Wardani, 2015). Namun hasil penelitian ini didapatkan bahwa responden yang memiliki SIM hanya 1,9 \% saja. Hal ini karena untuk untuk mendapatkan SIM salah satu syaratnya adalah usia 17 tahun sementara umur responden belum memenuhi syarat untuk memilki SIM, dengan kata lain bahwa responden belum mempunyai keterampilan dalam mengemudikan kendaraan sepeda motor karena belum mempunyai SIM. Kondisi ini dapat meningkatkan risiko kecelakaan lalu lintas pada siswa karena belum dimilikinya keterampilan/skill berkendara yang aman.

Hasil penelitian Soehodho menyatakan bahwa pengendara sepeda motor akan lebih agresif dan ceroboh karena mobilitas nya yang fleksibel, tren menunjukkan sepeda motor digunakan untuk perjalanan jarak jauh seperti perjalanan antarkota, 
dan penumpang lebih dari kapasitas dari dua orang yang mengendarai sepeda bukanlah hal yang tidak biasa (Soehodho, 2009). Penelitian Agus menunjukkan bahwa prediksi jumlah korban kecelakaan Lalu Lintas di Indonesia tidak hanya dipengaruhi jumlah penduduk dan jumlah kendaraan bermotor, tetapi juga jumlah kepemilikan SIM dan panjang jalan (Agus, 2012). Penelitian Marsaid menunjukkan bahwa pengendara tidak terampil berisiko 0,263 kali menyebabkan kejadian meninggal pada kecelakaan Lalu Lintas dibanding pengendara terampil (Marsaid, 2013).

Hasil penelitian menunjukkan bahwa pekerjaan orang tua responden $44,0 \%$ bekerja sebagai wiraswasta (petani, buruh, pedagang) dan tidak bekerja. Badan Kesehatan Dunia melaporkan bahwa kematian karena kecelakaan lalin dua kali lebih tinggi di negara berpenghasilan rendah dan menengah dengan penggunaan sepeda motor dominan, dibandingkan dengan negara berpenghasilan tinggi di dunia (WHO, Global Status Report on Road Safety, 2015). Kondisi sosial ekonomi keluarga dengan latar belakang ekonomi yang berisiko tinggi memengaruhi kemungkinan anak atau remaja meninggal atau terluka dalam kecelakaan lalu lintas. Hubungan kondisi sosial ekonomi keluarga tidak hanya antara penghasilan tinggi dan negara berpenghasilan rendah. Misalnya, data dari Swedia dan Inggris menunjukkan bahwa anak-anak dan orang dewasa muda berisiko mengalami kecelakaan lalu lintas lebih tinggi jika mereka berasal dari keluarga kelas sosial yang lebih rendah.

\section{Hubungan Merokok Saat Berkendara dengan Kecelakaan Lalu Lintas}

Berdasarkan hasil penelitian ini, kejadian kecelakaan juga diakibatkan karena merokok sambil berkendara $(\mathrm{p}=0,001)$. Persentase kejadian kecelakaan terdapat pada responden dengan perilaku selalu atau sering merokok saat berkendara sebesar $33,0 \%$. Hal ini menunjukkan bahwa pengaruh rokok sebagai zat adiktif dalam berkendara seperti penurunan konsentrasi. Penelitian Mangiaracina menunjukkan bahwa merokok menghasilkan risiko luar biasa untuk keselamatan di jalan, lebih dari penggunaan ponsel. Dalam kondisi kecanduan menghasilkan gangguan mengemudi yang cukup besar pada perokok, hal ini disebabkan karena kekurangan oksigen yang ditunjukkan, kehadiran karbon monoksida dan konsentrasi tinggi partikulat offine di udara bernafas di dalam kendaraan. sehingga perlu untuk mempromosikan informasi publik tentang risiko-risiko tersebut di antara orangorang (Mangiaracina, 2007).

Hasil penelitian Pamungkas menunjukkan bahwa karakteristik pengendara dapat berubah secara drastis dan cepat karena penggunaan alkohol, narkotika, rasa sakit, jenuh dan tidak nyaman dapat secara serius mengurangi efisiensi pengemudi (Pamungkas, 2014).

Pencegahan penyalahgunaan zat adiktif di kalangan remaja merupakan usaha yang penting, dan layak dipertahankan dan ditingkatkan demi mengurangi konsekuensi penggunaan zat adiktif dari semua perilaku berisiko tinggi termasuk kecelakaan kendaraan bermotor. Temuan baru menunjukkan bahwa karakteristik orang tua dirasakan sangat kuat pengaruhnya pada mengemudi berisiko tinggi yaitu pada anak muda atau remaja.

\section{Hubungan Penggunaan HP dengan Menelepon, SMS dan Mendengarkan Musik dengan Kecelakaan Lalu Lintas}

Penelitian yang dilakukan oleh Governors Highway Safety Association (GHSA) Amerika Serikat, menemukan bahwa menelepon atau berSMS pada saat mengemudi merupakan penyebab terbesar terjadinya kecelakaan di jalan raya. Penelitian Internasional pun mengungkapkan bahwa penggunaan ponsel saat mengemudi menyumbangkan satu dari setiap empat kecelakaan lalu lintas. Bahaya penggunaan ponsel saat berkendara bukan pada cara kita menggunakannya (termasuk memakai hands free), melainkan lebih pada topik pembicaraan atau apa yang sedang kita bicarakan saat itu. Jadi bahayanya adalah karena otak pengemudi dipaksa berpikir hal penting lainnya saat mengemudi, sehingga konsentrasi menjadi terpecah (Polda Jatim, 2018).

Faktanya adalah menggunakan ponsel saat berkendaraan ternyata jauh lebih berbahaya daripada berkendaraan saat mabuk. SMS saat berkendara 6 kali lebih memungkinkan menyebabkan kecelakaan dibandingkan berkendara saat mabuk. Hampir $23 \%$ kecelakaan disebabkan oleh menelepon menggunakan ponsel saat berkendara. Berkendara sambil menelepon bisa membuat otak bereaksi (meski masih remaja) seperti otak para manula yang berusia 70 tahun (Polda Jatim, 2018).

Penelitian telah menyarankan bahwa penggunaan ponsel saat mengemudi mengurangi konsentrasi dikarenakan remaja cenderung menggunakan ponsel mereka saat mengemudi 
(McCartt AT, 2006) (Walsh Sp, 2008). Selain itu, telah ditemukan bahwa pengemudi remaja lebih cenderung mengalami cidera berat jika menggunakan ponsel saat mengemudi (Neyens DM, 2008).

Penggunaan ponsel pada saat mengemudi mencerminkan tingkat hubungan kognitif dan perilaku penggunaan ponsel (Gauld CS, 2014). Studi telah mengungkapkan bahwa remaja yang menggunakan ponsel cenderung menunjukkan bahwa mereka akan menggunakan ponsel mereka dalam beberapa cara saat mengemudi, termasuk mengirim SMS, dan lebih jauh lagi, bahwa mereka sengaja menyembunyikan perilaku ini (Gauld CS, 2014) (White KM, 2012).

Sejalan dengan penelitian ini, tingkat kecelakaan lebih sering terjadi pada responden yang menggunakan ponsel dengan menerima telepon atau menelepon saat berkendara $20,6 \%$, perilaku penggunaan ponsel dalam berkendara seperti mengirim SMS 25,8\% pernah mengalami kecelakaan, tetapi pada responden yang tidak mengalami kecelakaan namun menggunakan ponsel saat berkendara juga cukup tinggi $31,7 \%$. Hal ini menunjukkan perilaku berisiko terjadinya kecelakaan saat berkendara. Sehingga diperlukan upaya pencegahan pada pengemudi remaja untuk berkendara aman di jalan raya dengan terus memberikan pendidikan dan sosialisasi aman berkendara bagi berbagai pihak seperti orang tua, sekolah dan kepolisian.

\section{Hubungan Berkendara Lebih dari 2 Penumpang dengan Kecelakaan Lalu Lintas}

Menurut Undang-Undang Nomor 22 Tahun 2009 tentang Angkutan Jalan telah mencantumkan larangan bagi setiap pengendara untuk membawa penumpang lebih dari satu orang. Hasil penelitian ini menunjukkan bahwa $47,0 \%$ responden menyatakan selalu berboncengan sepeda motor lebih dari 2 orang dan kejadian kecelakaan dikarenakan selalu membawa penumpang lebih dari 2 sebesar $26,6 \%$.

Menurut hasil penelitian Lestari, pelanggaran jenis ini dikarenakan menghemat biaya atau menghemat bensin yang digunakan, karena jarak dekat dan serah sehingga meringankan pengemudi untuk tidak kembali menjemput penumpangnya (Lestari, 2015). Penelitian Soehodho menyebutkan bahwa kecelakaan lalu lintas juga disebabkan karena penumpang lebih dari kapasitas dari dua orang yang mengendarai sepeda bukanlah hal yang tidak biasa (Soehodho, 2009).

\section{Hubungan Kepatuhan Terhadap Rambu-Rambu Lalu Lintas dengan Kecelakaan Lalu Lintas}

Perangkat pengatur lalu lintas merupakan suatu instrumen yang diperlukan untuk mengatur kelancaran arus lalu lintas di jalan raya. Selain itu juga dapat berfungsi untuk menurunkan tingkat kecelakaan dan hambatan lalu lintas.

Rambu lalu lintas adalah suatu tanda, simbol, isyarat atau semboyan yang bertujuan memberikan informasi atau petunjuk bagi pengguna jalan tentang kondisi jalan dan lingkungannya.

Kesadaran pengemudi terhadap rambu-rambu Lalu Lintas di jalan raya perlu ada peningkatan. Terutama pada rambu lalu lintas menunjukkan lampu kuning. Pada penelitian ini kejadian kecelakaan terjadi pada mereka yang memiliki perilaku selalu melanggar lampu kuning 19,9\%. Hal ini sejalan dengan penelitian Wong (2010), menyatakan bahwa kesadaran pada kondisi Lalu Lintas dan rambu-rambu lalu lintas akan bisa menurunkan kejadian kecelakaan di jalan raya (Wong, 2010). Lampu lalu lintas merupakan alat pengatur lalu lintas yang dijalankan dengan listrik atau sejenisnya yang bertujuan untuk mengatur, mengarahkan serta memberikan peringatan kepada pengguna kendaraan.

Pada penelitian ini, secara statistik menunjukkan hubungan dengan $p=0,015$ antara pelanggaran terhadap lampu lalu lintas seperti melajukan kendaraan di saat lampu lalu lintas dengan angka kecelakaan pada responden. Penelitian Handayani (2017) menunjukkan bahwa pelanggaran rambu dan lampu Lalu Lintas merupakan faktor yang paling berpengaruh terhadap potensi terjadinya kecelakaan Lalu Lintas yaitu sebesar 39,5\%. Penelitian Marsaid menunjukkan bahwa pengendara tidak tertib berisiko 0,227 kali menyebabkan kejadian meninggal pada kecelakaan lalu lintas. Data ini mencerminkan pengendara yang tidak tertib berisiko menyebabkan kecelakaan dengan korban meninggal dunia (Marsaid, 2013).

Hasil penelitian ini menunjukkan bahwa sebesar 34,0\% menunjukkan bahwa responden kadang-kadang menjalankan kendaraan dengan kecepatan tinggi pada saat lampu lalu lintas berwarna kuning. $48,0 \%$ responden pernah mengalami 
kecelakaan lalu lintas menyatakan selalu/sering mengendarai sepeda motor dengan kecepatan lebih dari $60 \mathrm{~km} / \mathrm{jam}$, hal ini sesuai dengan hasil penelitian Poei (2016), berarti gerak cepat untuk mengendarai kendaraan untuk mencapai tujuan sesegera mungkin adalah fenomena yang terjadi sekarang, tanpa menghiraukan etika berLalu Lintas yang ada.

Tidak ada hubungan yang signifikan terhadap pelanggaran perangkat pengatur lalu lintas yaitu pelanggaran terhadap marka jalan, rambu lalu lintas dan mengendarai kendaraan dengan kecepatan 60 $\mathrm{km} / \mathrm{jam}$. Hasil penelitian ini tidak sesuai dengan hasil penelitian Prakarsa (2011) yang menemukan bahwa kecelakaan lalu lintas terjadi akibat kecepatan yang lebih tinggi atau $>60 \mathrm{~km} / \mathrm{jam}$. Kecepatan yang lebih tinggi atau $>60 \mathrm{~km} / \mathrm{jam}$ berdampak pada dekatnya jarak antar kendaraan sedemikian sehingga jarak pandang henti ideal terlampaui dan kemampuan pengendalian kendaraan berkurang (Costa, 2012). Hampir dapat dipastikan akan berakibat fatal bagi pengendara sepeda motor dan pejalan kaki di lokasi/ jalan tersebut (Prakarsa, 2011).

\section{SIMPULAN}

Faktor penyebab kecelakaan Lalu Lintas pada siswa SMA di Kota Samarinda yaitu perilaku saat berkendara yang tidak aman yaitu perilaku melanggar lampu kuning, menelepon, mengirim SMS, merokok dan berkendara lebih dari 2 orang.

Hubungan antara kejadian kecelakaan dengan perilaku saat berkendara, menunjukkan adanya hubungan antara kejadian kecelakaan dengan perilaku melanggar lampu kuning $\mathrm{p}=0,015$, menelepon $\mathrm{p}=0,041$, mengirim $\mathrm{sms} \mathrm{p}=0,000$, merokok $\mathrm{p}=0,01$ dan berkendara lebih dari 2 orang $\mathrm{p}=0,043$. Perilaku berkendaraan lainnya seperti memacu kendaraan lebih dari $60 \mathrm{~km} / \mathrm{jam}$, mendengarkan musik, melanggar marka jalan dan melanggar rambu-rambu Lalu Lintas tidak memiliki hubungan dengan kejadian kecelakaan.

\section{UCAPAN TERIMA KASIH}

Ucapan terima kasih disampaikan kepada Direktorat Riset dan Pengabdian kepada Masyarakat, Direktorat Jenderal Riset dan Pengembangan Teknologi, Kementerian Riset, Teknologi dan
Perguruan Tinggi atas pemberian dana pada skim Penelitian Produk Terapan tahun anggaran 2017 dengan nomer kontrak: 360 / UN17.41 / KL / 2017.

\section{DAFTAR PUSTAKA}

Adinugroho, L., 2012. Karakteristik Pengemudi di Model Peluang Terjadinya Kecelakaan Bus AKAP. Jurnal Rekayasa Sipil, [e-Jurnal] 6(1): pp. $42-54$

Administration, N. H., 2008. Traffic Safety Facts 2008. A Compilation of Motor Vehicle Crash Data from the Fatality Analysis Reporting System and The General Estimates System. USA: National Highway Traffic Safety Administration

Agus, S., 2012. Perbandingan Model Andreassen dan Model Artifisial Neural Network untuk Prediksi Fatalitas Korban Kecelakaan Lalulintas. Jurnal Transportasi, [e-Jurnal] 12 (1): pp. 73-82

Costa, D. G., 2012. Analisis Risiko Kecelakaan Pengguna Sepeda Motor. Simposium XV FSTPT. Bekasi: Sekolah Tinggi Transportasi Darat

Disnas Perhubungan., 2013. Profil dan Kinerja Perhubungan Darat 2013. Jakarta: Kementerian Perhubungan Republik Indonesia

Rakhmani, F., 2013. Kepatuhan Remaja dalam Berlalu Lintas. Jurnal S-1 Ilmu Sosiatri, [e-Jurnal] 2(1): pp.1-7

Gauld C.S.L.I., 2014. Concealing Their Communication: Exploring Psychosocial Predictors of Young Drivers' Intentions and Engagement in Concealed Texting. Accid ent Analysis and Prevention, [e-Jurnal] 62:pp. 285293

Handayani, D., Rahma O., O., Widi, H., 2017. Pengaruh Pelanggaran Lalulintas Terhadap Potensi Kecelakaan Pada Remaja Pengendara Sepeda Motor.. Matriks Teknik Sipil, [e-Jurnal] : pp.838-843

Jalil, A., 2014. 2013, 83 Orang Tewas Kecelakaan di Samarinda. Jakarta: Sindonews.com

Kazantzis., 2012. Predictors of Chronic Trauma Related Symptoms in A Community Sample of New Zealand Motor Vehicle Accident Survivors. Cult Med Psychiatry 36 , 442-464

Kusumadewi, H.P., 2012. The Correlation Between the Social Support of Peer Group and Self Control towards the Obedience of The Rule 
in The Teenage Girls of the Assalam Modern Islamic Boarding School Sukoharjo. Jurnal Ilmiah Psikologi [e-Journal] 1(2): pp.1-10

Lestari., 2015. Analisis Pelanggaran Pengendara Motor terhadap Undang-Undang No 22 Tahun 2009 Tentang Lalu Lintas dan Angkutan Jalan (Studi Kasus Pada Satlantas Kepolisian Resor Subang Jawa Barat). Skripsi. Surakarta: Universitas Muhammadiyah Surakarta

Mangiaracina G.P.L., 2007. Smoking While Driving and Its Consequences on Road Safety. Pub Med, 19 (3): pp.253-267

Marsaid., M.Hidayat, Ahsan., 2013. Faktor Yang berhubungan dengan Kejadian Kecelakaan Lalu Lintas Pada Pengendara Sepeda Motor di Wilayah Polres Kabupaten Malang. Jurnal Ilmu Keperawatan, [e-Jurnal] 1 (2): pp.98-112

McCartt A.T.H.L., 2006. Cell Phones and Driving: Reviewing of Research. Traffic Inj. PubMed, 7:89-106 doi:10.1080/15389580600651103

Neyens D.M.B.L., 2008. The Influence of Driver Distraction on The Severity of Injuries Sustained by Teenage Drivers and Their Passengers. Accident Analysis \& Prevention, [e-Journal] 40 (1): pp:254-259 doi:10.1016/j.aap.2007.06.005

Notoatmojo, S., 2010. Promosi Kesehatan: Teori dan Aplikasi. Jakarta: PT. Rineka Cipta

Pamungkas, N.S., 2014. Mengenal Perilaku Pengendara Kendaraan dalam Upaya Mencegah Terjadinya Kecelakaan di Jalan Raya. Teknis, [e-Junal] 9 (1): pp.13-18

Poei, E.P., 2016. Perilaku Berlalu Lintas Yang Mendukung Keselamatan di Jalan Raya. Teknik Sipil, [e-Jurnal] 14 (1): pp.10-19

Polda Jatim, D., 2018 Bahaya Penggunaan Handphone Saat Mengemudi. Surabaya: Polisi Daerah Jawa Timur

Howard, E., 2011. Keselamatan Jalan, Membangun Kapasitas Kelembagaan, Peran Polisi Lalu Lintas, Perspektif Seorang Ahli Keselamatan Jalan, Sisi Kemanusiaan, Infrastruktur. Jurnal Prakarsa Infrastruktur Indonesia, [e-Jurnal] 8: pp.3-9
Rahmawati., 1998. Korelasi Surat Ijin Mengemudi (SIM) dengan Kecelakaan yang Terjadi di Jalan. Tugas Akhir. Yogyakarta: Program Sarjana Ekstensi Teknik Sipil Universitas Gajah Mada

Rahmi, S., 2009. Analisis Perilaku Siswa SMA di Kota Samarinda dalam Berkendara Roda Dua terhadap Keselamatan Berlalu Lintas. Refleksi Kesehatan, pp. 32-67

Soehodho., 2009. Road Accident in Indonesia. IATSS RESEARCH [e-Journal] 33 (2): pp.122-124

Walsh Sp, W.K., 2008. Dialling and Driving: Factors Influencing Intentions to Use A Mobile Phone while Driving. Accident Analysis \& Prevention, [e-Journal] 40(6): pp.1893-1900.doi:10.1016/j. aap.2008.07.005

Wardani, V.A., 2015. Persepsi Masyarakat Terhadap Citra Polisi Lalu Lintas di Polsek Kecamatan Tampan Kota Pekanbaru. Jom Fisip, [e-Jurnal] 2(1): pp.1-15

White K.M. Shari P Walsh, Melissa K Hyde and Barry C Watson., 2012. Connection Without Caution? The Role of Mobile Phone Involvement in Predicting Young People's Intentions to Use a Mobile Phone While Driving. Journal of the Australasian College of Road Safety, [e-Journal] 23 (1): pp.16-21

WHO., 2013. Global Status Report on Road Safety. Geneva: World Health Organization

WHO., 2015. Global Status Report on Road Safety. WHO Librar.ed.doi:978 924156506 6. WHO/ $\mathrm{NMH} / \mathrm{NVI} / 15.6$

WHO., 2013. Road Traffic Injuries

WHO., 2015. Road Traffic Injuries

Wong., 2010. Determinants Behind Young Motorcyclist Risky Riding Behavior. Journal Accident Analysis and Prevention, [e-Journal] 42(1): pp.275-281 